\title{
NUWE WEË IN DIE KATEGESE
}

\author{
DS. C. J. SMIT
}

In die Kerk van die Reformasie het sedert enkele dekades 'n vernuwing en verhewiging in die belangstelling gekom vir die Kategese ten opsigte van sy plek in die struktuur van die kerklike verkondiging, sy inhoud en omvang en sy pretensie. Die inslag van hierdie interesse kom nie uit die gees van die nıodernisme en skeptisisme nie, maar, ek glo, ons moet dit eerder sien as 'n genadegawe van die Here van die Kerk wat Sy Kerk in die wêreld en tot heil van die wêreld in stand hou. Juis in die tyd waar die geroep, selfs uit die midde van die Kerk, opgaan: „God is dood", daar wil die lewends en lewendmakende Heer Sy Kerk daartoe bring om saam met die profete wat geprofeteer het oor die genade wat vir ons bestem is te ondersoek en na te vors wat die bedosling van die Gees met die Kerk en sy werkverrigting is in dic wêreld. (1 Petrus 1:10).

Hierdie nuwe weë wil dus niks anders wees nie as 'n gehoorsamc luister na wat dic Skrifte sê en 'n gefundeerde teruggryp na die beginsels van die Reformasie wat uitgekristaliseer het na grondige Skrifondersoek.

On te kan bepaal wat dia bedoeling van die Bybel met die kerklike kategese is, sal ons moet let op die samehang wat daar bestaan tussen die verskillende elemente van die kerklike verkondiging.

\section{Samehr.ng Tussen Kategese en Prediking:}

By die verbale gestaltes van die verkondiging tref ons die voorgemeetelike media aan waarin en waardeur God Hom wil rig tot die mens wat Hom nie ken nie. Ons wil veral let op die Kerugma en die Euangelion.

\section{IEERUGMA:}

Die Keruks, draer van die Kerugma, is die aankondiger van 'n boodskap van openbare belang. Die noodwendigheid dat die boodskap deurgegee word, lê in die bedoeling van die Opdraggewer. God wil Sy heil laat verkondig, proklameer onder hulle wat Hon nie ken nie. Die intoud van die boodskap is die nuwe en beslissende gebeure dat die koninkryk van die hemele naby gekoln het - dit vaarop die profete gewys en gewag het. „Die cpgaande Lig uit die hoogte het ons besoek om ta skyn oor die wat in duisternis en skaduwce van die dood sit, om ons voete na die pad van vrede te rig" (Luk. 1:78 en 79). Die vervullende 
en voleindigende handeling van God beteken volgens $\mathrm{C}$. $\mathrm{H}$. Dodd: „Die Profesië is vervul en die nuwe eeu het aangebreek in die koms van Jesus Christus. Hy is gebore uit die geslag van Dawid. Hy het gesterf volgens die Skrifte om ons uit die teenswoordige bose eeu te verlos. Hy is begrawe. Hy het op die derde dag opgestaan volgens die Skrifte. Hy sit aan die regterhand van God as die Seun Gods en as Heer van die lewende en die dode. Hy sal weer kom as Regter en Verlosser van mense" (De Apostolische Prediking in haar ontwikkelingsgang, p. 20, soos aangehaal deur J. I. de Wet: Die Kerklike Verkondiging in die huidige Tydsgewrig, p. 12).

Hierdie verkondigde woord is 'n goddelike Woord en as sodanig 'n werkende mag wat ook skep dit wat verkondig word. Die verkondiging rig hom nie so seer op die verstaan van die hoorder nie, maar die doel is eerder geloof (1 Kor. 2:4). Jesus bring nie 'n nuwe leer wat die intellek aanspreek nie, maar dit is heilsgebeure van God wat aanvaar en geglo moet word.

\section{EUANGELION:}

Ons kan Euangelion eintlik sien as sinonieme gebruik vir Kerugma. Ook hier tree die heroutgedagte sterk na vore. Die blye boodskap wek juis die vreugde en blydskap as en waar dit gehoor word. Wat die boodskap tot werklike blye boodskap maak is dat dit Jesus Christus tot inhoud het. Die evangelie beteken vir Sy dissipels derhalwe die onthulling van die Messiasgeheim. Jesus Christus plaas self Sy dissipels onder opdrag om met hierdie evangelie na alle mense te gaan (Matt. 28:19). Hulle wat in verlorenheid en ellende sit, moet van God se kant hoor van die heil wat teenwoordig is. So mag en moet die Kerk God se sendeling in die wêreld wees. Die Here kom na die wêreld toe en roep Sy Kerk in die lewe om dan verder, steeds verder met Sy Kerk op pad te wees deur die wêreld na die voleindnig toe. Die voleinding sal kom as die blye boodskap aan almal gebring is.

„Ons wil egter nog die aandag daarop vestig dat die evangelisasie as handeling van die Kerk ook 'n gebeurtenis van die Kerk is. In hierdie verband wil ons daarop wys dat in die evangelisasie die Kerk gestig word. Dit word vir ons aangetoon in die feit dat die evangelisasie nooit 'n alleenstaande figuur is nie, maar as't ware sy vervulling en kompletering soek in die doop. Die doop is die inlywing in die Kerk. Daarom kan ons sê dat die evangelisasie wil dat die heidendom Kerk sal word." (J. I. de Wet, a.w. p. 17). 
Uit die voorgaande tree duidelik aan die lig dat die Here die voorgemeentelike gestaltes van die verkondiging gebruik en ,'n deur van geloof" open by die heidene en hulle so opneem in die salige gemeenskap met Jesus Christus in Sy Kerk tot lof van God. Die heidendom wat egter so Kerk geword het, is nie nou aan hulle self oorgelaat nie, maar in Sy sorgende genade wil die Here hulle in die geloof bewaar. Die opdrag van Jesus ('hristus in hierdie verband is van lewensbelang: "Gaan dan heen, maak dissipels van al die nasies, en doop hulle in die Naam van die Vader en die Seun en die Heilige Gees; en leer hulle om alles te onderhou wat ek julle beveel het." Matt. 28:19. Uit Hand. 2:37-47 sien ons hoe die evangelie die ongeloof mak tot geloof en so word deur die doop heen die Kerk in aansyn geroep. Opvallend is dat onmiddellik vermeld word (vs. 42) dat hulle volhard het in die leer van die apostels en in die gemeenskap.

Binne hierdie gemeenskap tree die Woord nou op in sy binnegemeentelike gestalte. Deur die binnegemeentelike verkondiging word die mens nou in sy allerheiligste geloof opgebou om in die Woorde van die Here te bly. In hierdie verband, die binnegemeentelike, staan die mense egter nie net onder die klank en krag van die Woord in sy liturgiese moment nie, dit wil sê die verkondiging wil nie net hulle lewe betref waar hulle in die erediens vergader is nie, maar die verkondiging wil hulle ook onder die Koningsheerskappy van God stel as dit in sy paraliturgiese momente tot hulle spreek. Deur die liturgiese elemente van die verkondiging, dit wil sê deur prediking en Sakrament laat die Here Hom Sondag na Sondag betuig as die Teenwoordige wat by Sy gemeente wil bly tot aan die voleinding van die wêreld. Maar die só gestrooide en gesterkte gemeente van Sondag staan nie in die week in 'n toestand van Heerloosheid nie. In hulle onderlinge verband en samehang met die liturgiese tree die paraliturgiese elemente in die week op as middele in die hand van God waarmee Hy Sy gemeente in Sy Woord en waarheid bewaar. Omdat laasgenoemde dieselfde inhoud het, naamlik Jesus Christus as Verlosser en Heer, vorm dit saam met die liturgiese elemente die een verkondiging van die Kerk. „Hulle staan eintlik so gerangskik dat die verkondiging die ganse lewe van Gods kinders hier op aarde dek" (J. I. de Wet, a.w. p. 143).

\section{DIDACHE:}

Die didaskalos het tot taak om hulle wat nie ten volle ingelig is nie tot volledige en noukeurige kennis van iets of iemand te bring. In die Nuwe Testament tref ons verskillende persone aan wat hierdie titel dra. Dat dit tot 'n selfstandige amp in die Kerk gegroei het, wil voorkom uit Gal. 6:6. Paulus word self genoem 
keruks kai apostolos kai didaskalos, 2 Tim. 1:11. Die Here wil die leraar en die leer wat deur hom gebring word gebruik om Sy heil voortgang te laat hê. Die leer het steeds betrekking op die Woord van God. Wesenlik het dit geen ander inhoud nie as Jesus Christus die Verlosser. (Hand. 18:25, 28:31). „As iemand iets anders leer en nie instem met die gesonde woorde van onse Here Jesus Christus en met die leer wat volgens die godsaligheid is nie, die is verwaand en verstaan niks nie,... " ( 1 Tim. 6:3 en 4). Die leer kan nooit voortkom uit die mens as sy breinvrug, as resultaat van sy denkvermoë nie. Die oorsprong daarvan is bo en buite hom. Selfs Jesus Christus sê: „My leer is nie myne nie, maar van Hom wat My gestuur het." (Joh. 7:16). Waar van die gesonde leer afgewyk word, word die eer van God nie gedien nie en die gemeente van die Here nie gebou nie. So 'n valse en dwaalleer word afgewys. Dat die Kerk voortdurend moet waak $\mathrm{cm}$ reg en noukeurig te leer, is sy onvervreembare opdrag en roeping. Die leer wil niks meer of minder wees nie as die ontvouing van die sin en konsekwensies van dit wat in die Kerugma van dic Openbaring betuig is. Dit is ,vir ons duidelik dat ons hier te doen het met sistematiserende verduideliking van die aangekondigde heil binne die gemeenskap van hulle wat reeds die evangelie gehoor en geglo het. Hierdie tweede gestalte van dis verkondiging as gesonde leer is afwyking van die dwaalleer deur noukeurig en verstaanbaar die ding aangaande die Heer te leer. Deur die leer laat God die heilsmededeling voortsit tot vermeerdering van Sy eer." (J. I. de Wet a.w. p. 21).

Die begrip Katechein - om van bo af te laat klink - toon duidelik aan dat dit spreke is wat sinvol en gesagsvol aangewend word om die waarheid aangaande Jesus Christus "van voor af", noukeurig en in volgorde te betuig, ,sodat u met volle sekerheid kan weet die dinge waaromtrent $u$ gekatkiseer is" (Luk. 1:3 en 4). Deur die noukeuriger uitleg van die weg van God word die só geleerdes deur die genade vir die gelowiges tot veel nut, want die vollediger kennis is vir hom 'n lewende en bekwaammakende krag. Hier moet die Kerk met sy kategese aansluit. Die kennis van die weg van die Here is sy sterkte en sy hoop, terwyl die gebrek daaraan hom, waar hy liggaam van die Here is en moet wees, maak tot 'n hulpelose en hopelose liggaam. (Hand. 18:25).

Daar word ook ander gestaltes van die verkondiging in die Nuwe Testament aangetref wat teen die agtergrond van die leer gesien en verstaan kan word. 


\section{HOMILIA:}

Dit dui aan 'n gesprek wat gevoer word, gewoon of godsdienstig van aard. Vir ons doel is laasgenoemde van belang. Hierdie gesprek kan gevoer word tussen 'n gelowige en ongelowige, dus missionêr van aard en opset en geleentheid om die evangelie uit te dra. (Verg. die gesprek tussen Paulus en Felix, Hand. 24:26). Tweedens is dit die gesprek tussen gelowiges (Emnaüsgangers Luk. 24:13 vv). Uit die wedersydse ondervraging probeer hulle tot 'n beter begrip van die dinge te kom wat gebeur het. Die opgestane Heer open self vir hulle die Skrifte deur aan hulle uit te lê van Moses en al die profetc af die dinge wat op Hom betrekking het. Derdens is dit die spreke tot hulle wat in die erediens versamel is (Hand. 20:7-11), dus prediking.

\section{PROFETEIA:}

Dat die profeet mag profeteer, is nie aan homself geleë nie, maar dis 'n charisma van die Heilige Gees aan die gelowiges. Die spreke is gebonde aan die getuienis van Jesus Christus tot opbou van die gemeente. Die gemeente is betrokke by die spreke van die profeet waar hy verkondiger en uitlegger is van die openbaring van God. Hy staan onder die voorwaarde dat hy moet ondersoek en navors wat die bedoeling van die Heilige Gees is. (1 Petr. 1:10). Jesus die groot Profeet stuur Sy profete na die mense toe, en hulle profesie beoog die opbouing, troos en bemoediging van die gemeente.

\section{PARAKLESIS:}

Hierdie woord kom in verskillende betekenisse in die Nuwe Testament voor. Hoofsaaklik wil dit dui op troos, bemoediging, beraad, dringende versozk en selfs sedelike vermaning. Die troos wat die gelowiges van God ontvang, is die sterkende krag wat. hulle in staat stel tot die spreek en doen van goeie woorde en werke. Omdat hierdie troos steeds sien op Jesus Christus in en deur wic die Vader ons vertroos het, sal die troostende spreke van die gelowiges troostende spreke-in-Christus na buite wees. Aan die hand van die gesonde leer is dit 'n middel tot vermaning en weerlegging van die teësprekers. Dit is oproep tot geloof en volharding in die geloof en ook afwering van die dinge wat die geloof kan ondermyn. God bly in laaste instansie die Vertrooster van die gemeente want ook hierdie spreke het niks anders tot inhoud nie as Jesus Christus die Verlosser en Saligmaker. In Sy plaasvervangende lyde en sterwe wil $\mathrm{Hy}$ inderdaad vir ons die Trooster wees. Die ander Trooster, die Heilige Gees, Hy verheerlik Jesus Christus deurdat Hy neem wat aan die Seun behoort en aan 
die gelowiges verkondig en hulle so in alle waarheid lei. (Joh. 16:13 en 14). Hy bly by ons tot in ewigheid en Hy tree vir ons in by die Vader met onuitspreeklike sugtinge. (Rom. 8:26).

Uit voorgaande is dit duidelik dat:

a Die kategese integrale deel uitmaak van die kerklike verkondiging.

b. Die vervlakking of verwaarlosing daarvan beteken dat die eer van God nie gedien word nie en die gemeente nie gehou word nie.

c. Indien die Kerk die opdrag aan hom sou verontagsaam, verval hy nie net nie, maar hy word ook 'n verhindering, 'n struikelblok vir God. (Matt. 16:23).

d. Waar dit na die bedoeling van die Skrifte beoefen word, wil die Here dit gebruik om die synes in die geloof te bewaar en Sy ewige heil daardeur te laat voortgang hê.

\section{ONTWIKKELING EN AFWYKING:}

Uit die oud-christelike gegewens blyk genoegsaam dat die kategese werksaamheid binne gesinsverband 'n besondere plek ingeneem het. Daarbenewens is die leeraktiwiteit steeds as 'n amptelike funksie van die Kerk gesien en vervul deur die episkopos en die diakonos, terwyl die didaskalos in hoë aansien was by die gemeentes. Volgens Didache 11:1 word die gemeentes aangespoor om sulke manne te ontvang soos die Here self as hulle kom om onderrig te gee "tot vermeerdering van geregtigheid en die kennis van die Here". Die onderrig handel oor die volgende sake: Verordeninge vir die lewe van die gelowiges; uiteensettinge oor die Doop en die Nagmaal met die Onse Vader daarby; voorskrifte vir die gemeente en voorganger en ten slotte 'n oproep tot waaksaamheid. 'n Belangrike aspek van die onderrig is dat dit sterk missionerend van aard is, want dit wil onderrig wees vir hulle wat uit die heidendom kom. Die onderrig geskied met die oog op die doop van diesulkes. Hierdie onderrig het twee jaar geduur en dikwels selfs drie jaar. Die onderrig was nie net leer van die voorgeskrewe stukke nie, maar dit moes dien as vorming tot ' $n$ christelike lewe in diens van God en barmhartigheid teenoor die naaste. Dit was 'n vereiste dat persone uit die gemeente kon getuig dat die katkisante die weduwees help en die siekes besoek.

Die kinderdoop is egter net so oud as die christelike Kerk. (Ins moet derhalwe in gedagte hou dat daar katkisasie was voor en na die doop. Aan die bekeerlinge uit die heidendom is die katkisasie gegee met die oog op die doop en die daarmee gepaardgaande openbare geloofsblydenis. $\mathrm{Na}$ ' $\mathrm{n}$ verdere kort onderrig is 
hulle ook tot die nagmaal toegelaat. Aan die kinders van die gelo wiges wat reeds gedoop is, is die katkisasie gegee met die oog op die toelating tot die nagmaal.

Sedert die vyfde eeu merk ons 'n verval in die leeraktiwiteit van die Kerk. Pous Gregorius die Grote, in die sesde eeu, het geen geringe aandeel hierin gehad nie met sy opvatting dat die prediking nie wesenlik noodsaaklik is nie en as dit dan moet beoefen word, kan dit goedskiks deur 'n diaken behartig word. Die sakramente word daarenteen gesien as die noodsaaklike heilsmiddele wat die genade direk ingiet en so van die ontvangers beter mense maak. Met die opkoms van die bieg is verder in die rigting beweeg dat 'n grondige kennis van die Skrifte oorbodig geword het. Dit was slegs nodig om die opgestelde sondelyste te ken. Die Kerk het hier aangeland by die leer van die goeie werke waar verdienste groter gewig dra as geloof.

\section{DIE KERKHERVORMING:}

So vroeg as 1294 het Jan van Zyric, biskop van Utrecht, vir die kategese voorgeskryf die Onse Vader, Credo, Tien Gebooie en die Sakramente. Die Credo en die Onse Vader moes elke Sondag verklaar word en die Tien Gebooie en die Sakramente moes een keer per kwartaal uitgelê word. Hoewel dit nog nie veel meer beteken het nie as 'n blote voorlesing van die stof, moet ons tog hierin die voortekens sien van verdieping in die kategetiese arbeid. Die voorlopers van die Reformasie het ten opsigte van die kategese op drieërlei wyse invloed laat geld:

1. Die kennis moes by die jeug bygebring word as 'n persoonlike verwerkte onderrig, eerder as die blote opsê van formules.

2. 'n Kategismus was vir hulle nie bloot 'n leerboek nie, maar ook en veral die uitdrukking van 'n gemeenskaplike belydenis van christene.

3. Die jeug moes allereers na die bron, die Heilige Skrif gelei word.

Die Hervormers hou vas aan die grondwaarheid dat God ons met Hom versoen deur Jesus Christus. Die geloofsekerheid rus in die versoenende sterwe van Jesus Christus en nie in die "absolvo te" van die biegpriester nie. Omdat God alleen geken word uit die Skrifte en omdat die mens alleen deur 'n opregte geloof geregverdig word en omdat hierdie geloof niks anders is nie as enkel genade van God daarom vra die kategese om diepgaande onderrig, noukeurige ondersoek en 'n aflegging van belydenis in die openbaar. So word die eer van God weer gedien en Sy Naam bely in die midde van die gemeente wat geroepe is om Sy Woord te verkondig en die Sakramente te bedien volgens die instelling van Christus. 
Calvyn skryf in 1548 aan die hertog van Somerset: „Glo my. die Kerk van God kan nie bestaan sonder kategismus nic. Sorg daarvoor dat die kinders onderrig word aan die hand van 'n goeie kategismus wat hulle in kort leer wat die ware christendom beteken." Tog word die klagte gehoor dat baie predikante nie opgewasse is vir die taak van die kategese nie. Wilhelmus a' Brakel skryf: „Ek kan nie sien hoe 'n predikant met 'n goeie gemoed kan lewe en sterwe nie as hy nie van die kategese sy werk maak nie."

Nie slegs uit die hoeveelheid van kategismusse wat die lig sien nie, maar voral uit hulle inhoud word duidelik dat die gemeente tot die besef ontwaak dat hy alleen uit die Woord kan lewe. Die hantering van die kategismus in die Pfalz gec blyke van die erns waarmee die saak bejeen is. By die oggenddiens is so 'n deel van die kategismus voorgelees dat dit in nege agtereen. volgende Sondae deurgelees is. Dus vyf keer per jjaar. Tydens die middagdiens het die kategismusprediking plaasgevind. Ter inleiding van die diens is die heel kleintjies kortliks onderrig aangaande sekere kardinale punte van die christelike leer. Daarna is die groter kinders ,,in bysyn van die gemeente" ondervra oor die vrae waaroor die preck sou handel. Nadat hulle dit by die skool of tuis geleer het, moes hulle dit hier kom opsê. Hierna het die eintlike kategismuspreek gevolg. Dit moes een keer per jaar deurgewerk word. Dit is betekenisvol dat ons die noue samehang tussen kategese en prediking hier opmerk.

\section{DIE SONDAGSKOOL:}

Die Rasionalisme met die daarby behorende Moralisme en die Piëtisme en Metodisme wat ' $n$ individualisme bring waarin die bekeerde mens hom heerlik koester, het 'n vrugbare teelaarde geskep vir die ontstaan van ondernemings soos die Sondagskool naas en los van die Kerk.

Die Sondagskool dank sy ontstaan aan die arbeid en ywer van Robert Raikes (1735-1811) uitgewer van die Gloucester Journal. Nadat hy hom 'n kwart eeu lank beywer het om misdadigers te rehabiliteer, het hy tot die gevolgtrekking gekom dat sy pogings vrugteloos sal bly as dit nie aangevul word deur cen of ander preventiewe program nie. Hy beskryf die grondoorsaak van die misdaad toe aan onkunde. Een van die misstande wat die Industrialisasie meegebring het, was dat die jong kinders ses dae in die week gewerk het en Sondag was die dag waarop bandeloosheid hoogty gevier het. Met geskenke en geld het hy sommiges na die Kerk gelok en om die res van die dag nuttig te bestee, het hy hulle die eerste beginsels van higiëne bygebring cn hulle ook leer lees uit die Bybel. 
As gevolg van die propaganda wat Raikes in sy koerant Ecmaak het vir die onderneming is die Sunday School Union in 1803 gestig.

Die teoloog en psigoloog George Hamilton Archibald, 'n lianadees, neem nie genoeë met die metode wat deur Raikes se onderneming gevolg word nie. Deur groot geldelike bydrae van clie Cadbury lekkergoedvervaardigers word hy in staat gestel cm die Westhill College op te rig vir die opleiding van onderwysers. Dit is uit hierdie College wat ons die Westhill Sondagskoolnetode het waar die bevatlikheidsvermoë van die kind van ccurslaggcwende belang is.

In navolging van hierdie werkwyse word daar in 1866 in Nederland oorgegaan tot die stigting van die Nederlandsche Zondagschoolvereeniging. Hier, net soos elders, staan gəlowiges aan dis spits, maar daar is geen sprake van dat dit die Kerk is wat in amptelike hoedanigheid sy kategetiese arbeid verrig nie.

Sedert 1916, nadat die Algemene Kerkvergadering dienaangaande ' $n$ besluit geneem het, het die Sondagskool inslag by die Ned. Hervormde Kerk van Afrika gekry. Hoewel dit kerklik ingeskakel is en gereël word, moet ons egter die toegewing maak clat dit nie heeltemal ontdoen is van alle eienskappe wat dit meegebring het uit die historiese agtergrond en milieu nie.

\section{NUWE RIGTING IN ONS KERK:}

Uit die agtergrond en ontwikkeling van die Sondagskoolwese tree verskillende apsekte en motiewe na vore wat die Kerk loor die onontwykbare noodsaaklikheid plaas om opnuut te vesin oor die plek en doel van die kategese.

a. Omdat sosiale probleme noodoptrede geverg het en die Sondagskool daargestel is om die verval te bekamp langs die weg van sosiale hervorming los van en langs die Kerk, hou dit die gevaar in dat dit die christelik-godsdienstige onderrig sy kerklike karakter ontneem. Die feite is dat die Sondagskool vandag nog deur sommiges gesien word as 'n plaasvervanger van die erediens.

b. Omdat die „verstaan" en „ken" vir baie nie verder strek as 'n moontlikheid wat uitsluitlik by die mens se kenvermoë berus om tot ' $n$ kennis van God te kom nie, daarom vind ons hier ' $n$ moraalleer wat vreemd is aan die heil in Jesus Christus. (im rekening te hou met die bevatlikheidsvermoë van alle mense (ook en veral van die kinders) is korrek. Maar wanneer dit verabsoluteer word as die enigste wyse waarop die mens tot die ware kennis kan kom, dan is die genade van die Heilige Gees reeds totaal buite rekening gelaat. So langs die weg van kennis- 
inname deur die verstand mag ons baie ken, maar dit bly die Bybelse waarheid: „en niemand kan sê dat Jesus die Here is nie, behalwe deur die Heilige Gees".

c. Die gevaar is nie onwesenlik nie dat waar die arbeid verrig word deur welmenende en gewillige persone dit 'n valse gerustheid by die ampsdraer van die Kerk bring dat die taak tog verrig is en dit dikwels op 'n wyse wat onverenigbaar is met die opdrag van die Kerk. Die amps- en ouerplig kan deur so 'n opvatting ondermyn en gereduseer word tot die punt van ongehoorsaamheid en pligsversaking.

d. Die Kerk het van die Here die opdrag om die Woord en die Sakramente te bedien sodat die gemeente by die Here bewaar kan word. Indien die Kerk nou toelaat dat die jong lidmaat 'n ekskurs neem in 'n atmosfeer wat tog vreemd is aan die Kerk, dan word sy latere terugkeer as 'n meelewende lidmaat van die liggaam van Christus sodanig bemoeilik en in gevaar gestel dat onkerklikheid nie meer 'n denkbeeldige gevaar is nie.

Deur dat die Kerk hom daarvan oortuig hou dat, op Bybelse gronde, die samehang tussen erediens en kategese nie sonder gevaar van diepe verval en verarming opgehef kan word nie, het die nuwe rigting in die Kerk sedert enkele jare sy beslag gevind. Dis noodsaaklik dat die gedoopte kinders van die gelowiges saam met die volwassenes in die erediens van die gemeente vergader en daaraan deelneem. Vanuit die erediens sal die kind van die Kerk moet groei en ken en glo om weer telkens daar sy geloof saam met die Kerk van al die eeue te kom bely. Binne die erediens het hy die doop ontvang en is so in die Kerk ingelyf. Onder die verkondiging is die Kerk nou met hom op pad na die ander Sakrament, die Nagmaal, in die vaste vertroue dat die volkome geregtigheid van Christus hom as sy eie toegereken en geskenk is. (Nagmaalsformulier). Van hieruit sal hy dan ook so gesind moet wees om voortaan met sy ganse lewe waaragtige dankbaarheid jeens God die Heer te bewys en voor die aangesig van God opreg te wandel.

Aan die begin van hierdie dekade is deur die Raad vir Sondagskool 'n memorandum aan die H.E. Kommissie van die Algemene Kerkvergadering voorgelê waarin, in die lig van die feit dat die kategese 'n paralelle funksionele plek met die prediking beklee, die volgende voorstel gedoen is:

„Die voorgeskrewe geskiedenis en teks vir die bepaalde Sondag moet duidelik en verstaanbaar behandel verklaar en toegepas word in die prediking. $\mathrm{Na}$ die afsluiting van die erediens bly die kinders agter in die kerkgebou en verdeel 
normaalweg in klasse waar die onderwysers dan die geleentheid kry om vas te stel of die kinders reg verstaan het of nie en om die leemtes wat daar nog mag wees, aan te vul".

Die H.E. Kommissie van die Algemene Kerkvergadering het dit in beginsel goedgekeur en sedertdien het twee Algemene Kerkvergaderings met insteming daarvan kennis geneem.

Dit moet dadelik gestel word dat die bedoeling nooit was dat die kategese vanuit die prediking sinvol en Skrifverbonde merk is juis dat die prediking Skrifgebonde prediking sal bly en dat die kategese vanuit die prediking sinvol en Skrifverbonde beoefen sal word.

Die kan ook nie gesien word dat die Raad aan die predikant wil voorskryf waaroor die prediking sal handel nie. Die Kerk bepaal immers dat by die prediking rekening gehou moet word met die kerklike jaar. Dit geld ewegoed ook vir die Lesrooster. Al sou die Lesrooster nie slaafs gevolg word nie, sal die stof van die prediking steeds relevante stof bly.

Langs hierdie weg kom ons by die opheffing van elke grond om een keer per kwartaal 'n sogenaamde kinderdiens te hou. Die Kerk wys op goeie gronde die hou van spesiale Sondae (bv. Polisie-Sondag, Moeder-Sondag, ens.) af. Ons kan seker nie regverdiging vind daarvoor dat die kind in 'n uitsonderingsposisie staan nie. Die ganse gemeente, volwassene en kind, staan almal en altyd voor die uitnodiging van die soekende Heer wat die gemeente in geleentheid stel om Hom onder die prediking deur die werking van die Heilige Gees te ontmoet. Hiermee, glo ons, is ook die kinderkerk die reg van bestaan ontneem. Die Kerk het seker genoeg lidmate wat een keer per kwartaal die erediens besoek. Daarom kan ons dit nie bekostig om, selfs op die vaagste wyse, by 'n lidmaat te suggereer dat gereelde kerkbesoek nie ' $n$ vereiste is om in die geloof bewaar te word nie.

\section{NOODWENDIGE VERANDERING IN DIE METODE VAN}

\section{KATEGETIESE ONDERRIG:}

Op enkele uitsonderings na, kry ons in die Ned. Hervormde Kerk net met die kinderdoop te doen. Omdat die doop aan die volwassenes nie so dikwels voorkom nie, gee dit egter aan ons geen gronde vir wanpraktyk en afwatering nie. Diesulkes moet gekatkiseer word met die oog op hulle doop en hulle most in die midde van die gemeente gedoop word op grond van hulle belydenis. Dit is vir die gedoopte die besondere geleentheid van sy opname in die Kerk en die Verbond van God. Daarom vra dit om die grootste erns van die gemeente en die ampsdraers 
wat in opdrag van die gemeente die doop bedien asook van hom wat die doop ontvang.

By die kinderdoop sal die kategese nooit uit die oog mag verloor nia dat die kind in die Verbond van God ingelyf is. Deur sy doop het hy lidmaatskap van die Kerk van die Here verkry. Deur die doop word hy steeds aangespreek om sy „reinigmaking en saligheid buite homself te soek". (Doopformulier). Hierdeur is hy genadiglik deur God op God aangewys. Die kategese sal biyke gee of die Kerk die bedoeling van God in hierdic opsig reg en goed verstaan. Met nougesette ywer sal die gemeente hom daaraan moet wy om dit wat God aan die gedoopte deur die cloop beloof en verseël het, bekend te maak en wel op so 'n vyse dat hy dit glo.

Indien ons nou met die kategese by die prediking aansluit, is hierdie sake op hulle plek en dan het hulle ook sin. 'n Metode wat dan gevolg kan word, sal in breë trekke só daaruit sien:

a. Die kleintjies, dit wil sê tot ongeveer elfjarige leeftyd:

i. Daar word begin deur vrae aan hulle te stel oor die prediking wat hulls pas aangehoor het. U:t hulle antwoorde sal blyk in welke mate verdere verduideliking noodsaaklik is. Hier kom nou ook die ouerplig tot gelding. Die ouer het hom immers tuis onderrig om die voorgeskrewe gedeelte vir die Sonding te ken. Deur na dia erediens, by huisgodsdiens, weer navraag te doen, kan die onderrig so ingeskerp word dat dit van blywende waarde sal wees. Ex. 12:26: „En as julle kinders julle vra: Wat betcken die diens daar? dan moet julle sê ... " (Sien Deut. 6:7 en 20 en Ps. 78:3-8.)

ii. Die voorgeskrewe perikoop word weer aan hulle voorgelees en vrae word daaroor gestel. $\Lambda_{3}$ dit vertel word, moet by die Bybeise feits en bedoeling gehou word en geen moraallessie mag hisraan verbind word nie!

iii. Hulle word gevra om die teks, wat hulle uit die hoof moes leer, op te sê.

b. Die groter kinders, die katkisante:

i. Hulle word allereers uitgevra oor die prediking. Dit is noodsaaklik want wanbegrip werk dwaling in die hand.

ii. Hulle moet reeds geleer word om die verband tussen die prediking en die kategese, dit wil sê die verband tussen liturgiese en paraliturgiese elemente van die verkondiging te begryp. 
iii. Hulle moet geleer word dat die lewe in die geloof beteken: Om God te ken, Sy Naam te bely en om uit hulle bəlydenis, die belydenis van die Kerk, te lcef. (Die ouers se plig hou nie op as die kind self kan loes nie!)

By die onderrig van die volwasse ongedoopte, sal die kategese 'n sterk evangelisasie-karakter hê, maar dit maak geeneen van die bogenoemde punte oorbodig nie.

Deur so n' werkwyse kan die arbeid van die Kerk uitloop op die volgende:

a. Die nodige kennis word op simpatieke en tog doelgerigte wyse bygebring.

b. Die katkisant sal tot die verstaan van die lewensbeslissende feit gebring word dat hy as 'n verantwoordeliks mens wat voor God leef en aan Hom behoort in die wêreld moet optrce.

c. Die katkisant sal dieper in die besef gelei word dat hy meelewende lidmaat van die liggaam van Christus is.

So, glo ek, kan die Kerk met sy kinders uitkom by sy eie bcdoeling soos dit uitgedruk is in die Kerkwet Hoofstuk IX Artikel 90: „Die kategese het tot doel om die jeug van die Kerk en hulle wat tot die Kcrk wil toetree te onderrig aangaandz die leer van die Kerk en die betekenis van hulle dooplidmaatskap van die Kerk waarin hulle opgeneem is deur die Doop, om hulle voor te berei vir die deslname aan die heilige Sakramente cn vir die aanvaarding van medeverantwoordelikheid vir die opbou van die Godsryk in die algemeen en van die Nederduitsch Hervormde Kerk in die besonder."

\section{TOERUSTING VAN DIE KATEGETE - OUERS EN AMPS. DRAERS:}

In tweërlei opsig mag daar nou bedenkinge geopper word:

1. Ons kan vra waar die tyd eenvoudig vandaan moet kom om alles gedoen te kry?

2. Dis vraag kan opgaan: Hoeveel ouers is werklik in staat on die verlangde te verrig? Ons kan hier volledigheidshalwe ook die kategete, anders as die predikante, noem.

1. Oor die tyd, of die gebrek aan tyd, hoef ons nie veel t: sè nie. Omdat ons dikwels by die finale katkisasic-jaar tot dio ontnugtering kom dat die katkisante niks weet nie, moet ons nou teen 'n tempo kennis probeer inprop wat nóg vir die katkisant, nóg vir die Kerk enige blywende waarde het. Beter opsig en tossig sal seker nie misplaas wees nie. Die opsig moet deur die Kerkraad uitgeoefen word oor die katkisant, sy ouzrs 
en die kategete self. Die Kerk het nie uit gewoonte of bygelowigheid die doop bedien nie. Derhalwe sal die Kerk ook moet waak teen die ontheiliging van Woord en Sakrament in hierdie verband. Tweedens, is ons so onvoorwaardelik aan die tyd verslaaf dat ons 'n lidmaat van sestien jaar die wêreld „halfklaar" instuur eerder as om in verantwoordelikheid voor God „die heiliges toe te rus vir hulle dienswerk, tot opbouing van die liggaam van Christus, totdat ons almal kom tot die eenheid van die geloof, en van die kennis van die Seun van God, tot 'n volwasse man en die mate van die volle grootte van Christus: sodat ons nie meer kinders mag wees nie wat soos golwe geslinger en heen en weer gedrywe word deur elke wind van lering, deur die bedrieëry van mense, deur sluheid om listiglik tot dwaling te bring;..." (Ef. 4:12-14).

2. Dat hierdie vraag tewete of die ouers en ampsdraers oor die nodige toerusting beskik, lankal tot verontrusting in die Kerk gevra moes word, is waar. Sedert die Kategismusprediking in verval geraak het, moes die Kerk hiervoor gewaarsku wees. Prof. B. J. Engelbrecht skryf in die Almanak van 1960 oor die kategismusprediking onder andere soos volg: „Wat ons gemeentes betref, dink ek dat dit vandag weereens nodig geword het cat daar intensiewe onderrig in die christelike geloof volgens reformatoriese belydenis sal plaasvind, ook in die liturgie, in in die prediking", p. 40 en ,Wanneer die binding tussen prediking en belydenis afgesny word, dan word die suiwere verkondiging van Gods Woord so dikwels verruil vir allerlei menslike belewenisse en ervarings, estetiese gevoelens, spekulatiewe wysbegeerte en sensasionele nuwighede" p. 38. Miskien moet ons nie net volstaan met die prediking nie. Dit sal die moeite loon om die moontlikheid te oorweeg om na die prediking tot informele gesprek te kom oor die Sondagsafdeling wat pas in die prediking behandel is. (Ten opsigte van die bespreking verwys ek na die gedagtes uitgespreek by Homilia en verder na die gebruik in die Pfalz). Met groot vrug kan die Kerk gerus uitbrei op die skamele twaalf afdelings wat jaarliks behandel moet word.

Soos by almal bekend is die Raad vir Sondagskool en Kategese reeds besig om 'n kursus aan te bied vir 'n Kategetediploma. Die hoop word gekoester dat ouers in groot getalle hiervoor sal inskryf. Die ideaal bly egter dat elke Kerkraadslid van hierdie geleentheid gebruik sal maak om homself te onderlê in hierdie belangrike afdeling van die werk waartoe hy geroep is.

Die bedoeling van die Raad met hierdie kursus is om die Kerk te dien sodat die Kerk in sy nie-amptelike en amptelike 
leeraktiwiteit sy taak so volbring dat:

i. Die hele evangelie in sy volle omvang en na sy eie bedoeling meegedeel kan word (vgl. Luk. 1:3 en Hand. 20:20 en 27).

ii. Die heilsfeite sistematies en in die regte volgorde bygebring word (Luk. 1:3).

iii. Die feite moet geken en verstaan word en die kennis en verstaan van die feite moet steeds noukeuriger meegedeel en gekontroleer word. (Hand. 18:26).

In die lig van en in gehoorsaamheid aan die opdrag van Jesus Christus: „en leer hulle om alles te onderhou wat Ek julle beveel het", hoop die Raad dat hierdie onderneming, wat beter toerus. ting op die oog het, die Kerk sal help om die kategese reg en goed te verrig.

En so, deur al die gestaltes van die kerklike verkondiging tot hulle reg te laat kom, kan die Kerk as die Bruid met heilvolle verwagting uitsien na die koms van die Bruidegom. 